\title{
DOES MONey MATTER IN THE ECB STRATEGy? NEW EVIDENCE BASED ON ECB COMMUNICATION
}

\author{
HELGE BERGER \\ JAKOB DE HAAN \\ JAN-EGBERT STURM
}

CESIFO WORKING PAPER NO. 1652

CATEgory 6: MONETARy POLICY AND INTERNATIONAL FinANCE JANUARY 2006

\footnotetext{
An electronic version of the paper may be downloaded

- from the SSRN website: www.SSRN.com

- from the CESifo website: www.CESifo-group.de
} 


\title{
DOes MONeY MATTER IN THE ECB STRATEGY? NEW EVIDENCE BASED ON ECB COMMUNICATION
}

\begin{abstract}
We examine the role of money in the policies of the ECB, using introductory statements of the ECB President at the monthly press conferences during 1999-2004. Over time, the relative amount of words devoted to the monetary analysis has decreased. Our analysis of indicators of the monetary policy stance suggests that developments in the monetary sector, while somewhat more important in the later half of the sample, only played a minor role most of the time. Our estimates of ECB interest rate decisions suggest that the ECB's words (monetarysector based policy intensions) are not an important determinant of its actions.
\end{abstract}

JEL Code: E58, E52, E43.

Keywords: ECB, communication, monetary policy.

\author{
Helge Berger \\ Free University Berlin \\ Department of Economics \\ Boltzmannstr. 20 \\ 14195 Berlin \\ Germany \\ hberger@wiwiss.fu-berlin.de
}

\author{
Jakob de Haan \\ University of Groningen \\ Department of Economics \\ PO Box 800 \\ 9700 AV Groningen \\ The Netherlands \\ jakob.de.haan@rug.nl
}

\author{
Jan-Egbert Sturm \\ ETH - Swiss Federal Institute of Technology \\ KOF \\ ETH Centre WEH \\ 8092 Zurich \\ Switzerland \\ sturm@kof.ethz.ch
}

This version, 9 January 2006 


\section{Introduction}

Ever since its inception, the European Central Bank (ECB) has been criticized for its monetary policy strategy (see De Haan et al., 2005 for a discussion). A particular controversial element in the ECB strategy is the role of money. ${ }^{1}$ In addition to a broad assessment of the risks to price stability (the so-called "economic analysis", previously called the "second pillar"), the ECB uses a quantitative reference value for the annual growth rate of a broad monetary aggregate (M3) to assess whether monetary developments pose a risk to price stability ("monetary analysis", previously called the "first pillar"). According to Jaeger (2003), initial ECB comments on its strategy suggested that money would be a dominant input into policy decisions. ${ }^{2}$ After an evaluation of its monetary policy strategy, the ECB Governing Council decided in May 2003 that the introductory statement of the ECB President after a Governing Council meeting will henceforth start with the economic analysis to identify short to medium-term risks to price stability. The monetary analysis will then follow to assess medium to longterm trends in inflation in view of the close relationship between money and prices over extended horizons. ${ }^{3}$ This decision was widely interpreted as implying that money has become less important in the ECB monetary strategy. For instance, according to De Grauwe (2003): "the ECB is downgrading the importance of the money stock (M3) in its monetary policy strategy, and rightly so. It just did not make sense anymore to pretend that the money stock is the most important variable to watch. This variable is so much polluted by noise that it rarely gave the right warning signal of future inflation."4 However, on various occasions, the ECB has stressed that, as in the past, the monetary analysis still plays a role in its monetary strategy. Still, according to Gerlach (2004), most econometric estimates of reaction functions for the euro area fail to find that money growth plays a role in the ECB's interest rate decisions. ${ }^{5}$

In this paper we examine the role of money in the ECB monetary policy strategy using the ECB's most important communication device, i.e. the President's introductory statement at the monthly press conference in which he reports on the decisions taken by the ECB's Governing Council. The statement is understood to reflect the position and

\footnotetext{
${ }^{1}$ Summarizing the critique, Gerlach (2004) argues that the ECB would be ill advised to disregard monetary factors, but that taking proper account of these does neither necessarily entail monitoring the growth rate of $\mathrm{M} 3$, nor does it require a separate monetary pillar.

${ }^{2}$ When, for instance, ECB President Duisenberg was asked during the press conference on 13 October 1998 on the relative importance of money he noted that “... it is not a coincidence that I have used the words that money will play a prominent role. So if you call it the two pillars, one pillar is thicker than the other is, or stronger than the other, but how much I couldn't tell you".

${ }^{3}$ Duisenberg explained these changes at the beginning of the press conference on May $8^{\text {th }}$, 2003: "The introductory statement will henceforth present first economic analysis, followed by monetary analysis. It concludes by cross-checking the analyses conducted under these two pillars."

${ }^{4}$ Similarly, Svensson (2003) summarizes the Governing Council decision as follows: "Keeping the twopillar strategy but reducing the prominence of the first pillar by putting it second and discussing the monetary pillar (relabeled "monetary analysis") after the "broadly-based assessment" (relabeled "economic analysis"), seeing it mainly as a means of "cross-checking" the "economic analysis". This is a change in the right direction, but it is not enough."

5 Recently, Carstensen and Colavecchio (2004) estimated several Taylor-type reaction functions for the ECB and conducted a structural change analysis using both recursive parameter estimates and structural change tests. They do not find clear-cut evidence in favour of a break after the revision.
} 
views of the Council, agreed upon on a word-by-word basis by its members, and - other than, for instance, the editorial included in the Monthly Report-focuses almost exclusively on matters of monetary policy. More specifically, we quantify and analyze the policy implication contained in the introductory statement: we extract the ECB's overall policy intention stemming from its aggregated view of the economy, and the ECB's views on certain disaggregated economic developments and their policy implications, in particular monetary indicators, price stability, and developments in the real economy.

Since monetary policy is increasingly becoming the art of managing expectations, communication has developed into a key instrument in the central bankers' toolbox in recent years. It is therefore no surprise that recently various papers on central bank communication have been published. Broadly speaking, this research can be distinguished in two (not mutually exclusive) groups of studies. The first group consists of studies examining communication strategies of central banks (e.g. Blinder et al., 2001 and Ehrmann and Fratzscher, 2005), while the second group consists of studies in which the effect of communication on financial markets is analysed (e.g. Fratzscher, 2004 and Jansen and De Haan, 2005a).

Two papers on ECB communication come close to ours. Like the present paper, Rosa and Verga (2005) transform the qualitative information of the ECB press conferences into an ordered scale, verifying empirically to what extent market expectations react to the information released by the ECB. They find that the public not only understands but also believes the signals sent by the European monetary authority. Heinemann and Ullrich (2005) also use the introductory statements by the ECB President at the monthly press conference to construct a wording indicator reflecting the "hawkishness" of monetary rhetorics, integrating this indicator into a standard Taylor type model for the interest rate. They find that the wording indicator can improve the model's fit when added to the standard explanatory variables. Our paper differs from these studies in two ways. First, we use the introductory statements of the ECB president for a different purpose, i.e. to examine whether the ECB's monetary policy strategy has changed. Second, we use a different method to transform qualitative information into quantitative information. Not only do we come up with an indicator of the ECB's overall policy intention stemming from its aggregated view of the economy, we also have indicators of the ECB's views on certain disaggregated economic developments coinciding with the "economic analysis" and the "monetary analysis".

Our main finding is that developments in the monetary sector did not play a significant role most of the time when explaining the overall policy stance as communicated by the introductory statements of the ECB president. Also when it comes to actual policy, our estimates of ECB interest rate decisions suggest that money never did significantly matter. There are indications that the role of money has slightly changed, but most likely this change occurred before May 2003.

The remainder of the paper is structured as follows. Section 2 outlines communication of the ECB on its monetary policy strategy in some detail and explains our methodology. Section 3 presents the outcomes of our analysis based on simply counting words, while sections 4 and 5 shows the results for our indicators of the monetary policy stance. The final section offers some concluding comments. 


\section{Quantifying communication by the ECB on its monetary policy strategy}

Researchers have highlighted three reasons why communication may prove useful for central banks. First and foremost, communication may be a very direct and effective tool to influence expectations. Therefore, it plays a seminal role in improving the effectiveness of policy and, consequently, the economy's overall performance (e.g. Blinder, 1998 and Bernanke, 2004). In some instances and under some circumstancessuch as when nominal interest rates are close to the zero lower bound-communication may even function as the sole tool to anchor and guide market expectations. Second, communication may be used to reduce noise in financial markets (e.g. Posen, 2003). Greater disclosure and clarity over policy may lead to greater predictability of central bank actions, which, in turn, reduces the uncertainty in financial markets. Finally, communication is indispensable from the perspective of central bank accountability. As central banks have become more independent over time, they have to pay closer attention to explaining what they do and what underlies their decisions. The increased use of communication is partly a logical consequence of this development (Issing, 2005 and De Haan and Eijffinger, 2000).

A number of factors make communication particularly difficult for the ECB. First, it is a relatively young international organization with a Council and staff reflecting the cultural heterogeneity of the euro area. Talking with "one voice" might be difficult under these circumstances. Indeed, Jansen and De Haan (2005b) show that statements by ECB officials are often contradictory. Second, the message of the ECB may not be easy to convey. As pointed out in the Introduction, the monetary policy strategy of the ECB differs from those of other central banks, containing elements of monetary and inflation targeting. As a result, surveys suggest that professional economists often feel that they do not have a good understanding of the ECB's policy (De Haan et al., 2005). ${ }^{6}$ Third, the ECB has to deal with a large number of different media coming from various countries and having different traditions. As Hämäläinen (2001) - at the time member of the Executive Board of the ECB - puts it: "communication is not easy in a pan-European context in which differing cultures, languages, traditions and motives affect how messages are interpreted by the different counterparties involved."

Central bank communication may use various channels: press conferences, minutes of the meetings of the decision-making council, monthly bulletins, speeches and interviews. One important communication device of the ECB is the introductory statement by the ECB President for the press after the meetings of the Governing Council. In the morning of its meeting days, the Governing Council decides whether or not to modify its key interest rates. In his introductory statement the President explains the reasons for such decisions and gives the ECB's opinions on the risks for price stability and growth. In its Monthly Bulletin of November 2002 (p.64), the ECB stated that "The President's introductory statement at the press conference provides a

\footnotetext{
${ }^{6}$ Even by its own accord, the European Central Bank (ECB) faces a communication gap. As Issing (2001) writes, "[o]n the one hand, few observers contest the success and credibility of the ECB in delivering on its primary objective and on the appropriateness of most of its policy actions in this regard... On the other hand, however, the overall perception of the ECB by the public, academics, financial analysts, market participants, and not least, journalists continues to remain - at best - rather mixed." Indeed, in an article in the Wall Street Journal the ECB is considered a central bank "that cannot master communication" (Sims and Wessel, 2000).
} 
comprehensive summary of the policy-relevant assessment of economic developments. It is structured along the lines of the ECB's monetary policy strategy and agreed by the Governing Council."

Thus, the information provided in the introductory statement allows answering a number of questions. For instance, what is the relative importance of the "monetary analysis" for ECB communication compared to the "economic analysis"? Or, more pointedly, does the ECB pay more than lip-service to the monetary analysis? Moreover, has the relative importance of the monetary analysis changed over time? In particular, did the ECB indeed downgrade the former "first pillar" of it policy-making framework in May 2003? As discussed above, in May 2003 the ECB changed the structure of the introductory statement, highlighting the importance of non-monetary (or economic) issues. The Council stressed that the "new structure of the introductory statement will better illustrate that these two perspectives [i.e. the economic and the monetary analysis] offer complementary analytical frameworks to support the Governing Council's overall assessment of risks to price stability", and it argued that, as in the past, monetary analysis will take into account developments in a wide range of monetary indicators including M3, its components and counterparts, notably credit, and various measures of excess liquidity. However, a number of academic observers (like De Grauwe, 2003 and Svensson, 2003) have interpreted these changes as an important step away from Bundesbank-style monetary targeting.

Our data set consists of a total of 68 introductory statements of press conferences held after the meetings of the Governing Council. Our first observation is on January $7^{\text {th }}$, $1999{ }^{7}$ the last one is on December $2^{\text {nd }}, 2004$. We proceed in two steps. As a first step we will simply count words to analyse whether - and if so, when - the monetary analysis has become less important. The next step is to quantify the informational content of the introductory statement. The statement generally starts with a brief summary of the decision taken and the reasons underlying this decision, sometimes combined with an outlook on the future monetary policy stance endorsed by the Governing Council. Mainly based on this first section and the concluding section often added toward the end of the statement, we compute an indicator for the overall monetary policy stance communicated by the Governing Council. The indicator categorizes the overall monetary policy stance on a scale from -3 (strong inclination to lower rates); $-2 ;-1 ; 0$ (neutral) $+1 ;+2$; and +3 (strong inclination to increase rates). ${ }^{8}$ Furthermore, in line with the contents of the introductory statement we distinguish the implied policy stance for three subcategories based on the communicated information on: (1) price stability, (2) the real economy, and (3) monetary indicators. In all three cases, we compute the indexes exclusively based on the information contained in the dedicated sections of the introductory statements, excluding the introductory and concluding sections. Table 1 provides some examples for the three subcategories. As with the overall stance, these statements have been categorized on a scale running from -3 to +3 .

\footnotetext{
${ }^{7}$ Hence, we neglect the seven press conferences held by the ECB before the introduction of the euro, i.e. before January $1^{\text {st }}, 1999$.

${ }^{8}$ This is similar to Rosa and Verga (2005); Heinemann and Ullrich (2005) only distinguish between easing, neutral and tightening.
} 
Table 1: The introductory statement of the ECB President: some examples

\begin{tabular}{|c|c|c|c|c|c|c|c|c|c|}
\hline ate: & Prices: & & eam & Real economy: & Tea & & & Money: & Team \\
\hline & & & 23 & & 1 & 2 & & & 123 \\
\hline 4 -Feb-99 & $\begin{array}{l}\text { confirmed its earlier assessment } \\
\text { that the outlook for price stability } \\
\text { remains favourable; there are no } \\
\text { significant upward or downward } \\
\text { pressures on prices in the short } \\
\text { term }\end{array}$ & 0 & $\begin{array}{ll}0 & 0\end{array}$ & $\begin{array}{l}\text { confirm our earlier assessment that } \\
\text { there are downside risks for output } \\
\text { growth }\end{array}$ & -1 & -1 & -1 & $\begin{array}{l}\text { M3 growth remained very close to } \\
\text { the reference value; particular the } \\
\text { developments in credit growth will } \\
\text { need to be carefully monitored in } \\
\text { the coming months }\end{array}$ & $\begin{array}{lll}0 & 0 & 0\end{array}$ \\
\hline 9-Sep-99 & $\begin{array}{l}\text { we remain vigilant taking into } \\
\text { account the upward risks to price } \\
\text { stability; expectations for inflation } \\
\ldots . . \text { tend to indicate that markets } \\
\text { still expect an evolution of } \\
\text { consumer prices, which will } \\
\text { remain compatible with price } \\
\text { stability }\end{array}$ & 1 & $\begin{array}{ll}1 & 1\end{array}$ & $\begin{array}{l}\text { upturn in economic growth in the } \\
\text { course of this year }\end{array}$ & 0 & 0 & 2 & $\begin{array}{l}\text { recent monetary developments } \\
\text { merit close attention; shorter-term } \\
\text { monetary developments need to be } \\
\text { interpreted with caution }\end{array}$ & $\begin{array}{lll}2 & 1 & 3\end{array}$ \\
\hline $5-J a n-00$ & $\begin{array}{l}\text { consumer price developments are } \\
\text { expected to remain subject to } \\
\text { further upward pressure; stability- } \\
\text { oriented behaviour is urgently } \\
\text { required }\end{array}$ & 2 & 22 & $\begin{array}{l}\text { confirmed the widely expected } \\
\text { upturn in growth }\end{array}$ & 1 & 1 & 3 & $\begin{array}{l}\text { no...need to extend the current } \\
\text { situation of abundant liquidity; } \\
\text { liquidity conditions...continue to } \\
\text { be generous }\end{array}$ & 233 \\
\hline 14-Dec-00 & $\begin{array}{l}\text { Governing Council judges the } \\
\text { risks to price stability still to be on } \\
\text { the upside }\end{array}$ & 2 & $\begin{array}{ll}2 & 3\end{array}$ & growth continues to prevail & 0 & 1 & 2 & $\begin{array}{l}\text { caution continues to be warranted } \\
\text { with regard to the upside risks to } \\
\text { price stability stemming from the } \\
\text { monetary side }\end{array}$ & 112 \\
\hline 10-May-01 & $\begin{array}{l}\text { upward risks to price stability over } \\
\text { the medium term have diminished } \\
\text { somewhat }\end{array}$ & 1 & $\begin{array}{ll}0 & 0\end{array}$ & $\begin{array}{l}\text { actual economic growth will } \\
\text { nevertheless be broadly in line } \\
\text { with trend potential growth }\end{array}$ & 0 & 0 & 1 & $\begin{array}{l}\text { monetary developments no longer } \\
\text { pose a risk to price stability }\end{array}$ & $\begin{array}{lll}0 & 0 & 0\end{array}$ \\
\hline $11-$ Oct- 01 & $\begin{array}{l}\text { interest rates at the current } \\
\text { juncture is therefore seen as } \\
\text { consistent with maintaining price } \\
\text { stability over the medium term }\end{array}$ & 0 & $\begin{array}{ll}0 & 0\end{array}$ & $\begin{array}{l}\text { continue to monitor downside } \\
\text { risks to the current situation }\end{array}$ & -1 & 0 & 0 & $\begin{array}{l}\text { we do not judge that monetary } \\
\text { developments signal risks to price } \\
\text { stability ... the developments of } \\
\text { M3 will have to be monitored } \\
\text { carefully in the coming months }\end{array}$ & $\begin{array}{lll}1 & 0 & 2\end{array}$ \\
\hline 2-May-02 & $\begin{array}{l}\text { prospects for price stability appear } \\
\text { to be somewhat less favourable } \\
\text { than they were towards the end of } \\
\text { last year }\end{array}$ & 1 & $\begin{array}{ll}1 & 2\end{array}$ & $\begin{array}{l}\text { GDP growth rates in the euro area } \\
\text { should again be in line with } \\
\text { potential growth later this year; } \\
\text { still a number of uncertainties } \\
\text { surrounding the strength of the } \\
\text { current upswing }\end{array}$ & 0 & 0 & 1 & $\begin{array}{l}\text { some normalisation in the } \\
\text { development of M3 }\end{array}$ & $\begin{array}{lll}1 & 0 & 2\end{array}$ \\
\hline 7-Nov-02 & $\begin{array}{l}\text { further increase in the annual rates } \\
\text { of inflation around the turn of the } \\
\text { year and a delay in the return to } \\
\text { inflation rates below } 2 \% \text { cannot be } \\
\text { ruled out; this further increase } \\
\text { should only be temporary }\end{array}$ & 1 & $\begin{array}{ll}-1 & 1\end{array}$ & $\begin{array}{l}\text { Governing Council has discussed } \\
\text { extensively the arguments for and } \\
\text { against a cut in the key ECB } \\
\text { interest rates. The view has } \\
\text { prevailed to keep interest rates } \\
\text { unchanged. However, the } \\
\text { Governing Council will monitor } \\
\text { closely the downside risks to } \\
\text { economic growth in the euro area }\end{array}$ & -3 & -1 & -1 & $\begin{array}{l}\text { more liquidity is available than } \\
\text { would be needed to finance } \\
\text { sustainable, non-inflationary } \\
\text { growth. However, given the } \\
\text { current economic environment, we } \\
\text { do not see the risk of this } \\
\text { translating into inflationary } \\
\text { pressure in the near future }\end{array}$ & $\begin{array}{lll}1 & 0 & 3\end{array}$ \\
\hline 8-May-03 & $\begin{array}{l}\text { current monetary policy stance } \\
\text { remains consistent with the } \\
\text { preservation of price stability over } \\
\text { the medium term }\end{array}$ & 0 & $\begin{array}{ll}0 & 1\end{array}$ & $\begin{array}{l}\text { important downside risks to the } \\
\text { economic recovery have } \\
\text { diminished; nevertheless, there } \\
\text { continue to be downside risks }\end{array}$ & -1 & -2 & -1 & $\begin{array}{l}\text { euro area economy continued to } \\
\text { accumulate liquidity significantly } \\
\text { above the amount needed to } \\
\text { sustain non-inflationary growth }\end{array}$ & $2 \begin{array}{lll}2 & 1 & 3\end{array}$ \\
\hline 4-Nov-04 & $\begin{array}{l}\text { there are upside risks to price } \\
\text { stability over the medium term; } \\
\text { strong vigilance is therefore } \\
\text { warranted with regard to all } \\
\text { developments which could } \\
\text { increase such risks }\end{array}$ & 3 & $\begin{array}{ll}1 & 1\end{array}$ & $\begin{array}{l}\text { basic determinants of economic } \\
\text { activity remain consistent with } \\
\text { continuing economic growth in } \\
2005 \text {; outlook is surrounded by } \\
\text { continuing uncertainty }\end{array}$ & 0 & 0 & 1 & $\begin{array}{l}\text { remains substantially more } \\
\text { liquidity in the euro area than is } \\
\text { needed to finance non-inflationary } \\
\text { growth; this could pose } \\
\text { inflationary risks in the future if } \\
\text { the excess liquidity is not } \\
\text { progressively reduced }\end{array}$ & \\
\hline
\end{tabular}

Note: These quotes are selective and do not exhaust the information used to compute the policy intention indicators. See the main text for an explanation of the scores listed under the header of "Team". 
As pointed out Rosa and Verga (2005), the task of categorizing is helped to some extent by the fact that the language employed in the introductory statements is - to a degree - standardized, with a number of key words or strings reappearing with some regularity. Examples of (strings of) such key words are: "appropriate", "in line with", "for the time being", "carefully monitor", "vigilant", "upward/downward risks", "more/less favourable", "uncertainties", "tilted to the up/downside", "inflationary pressures", and "above/below potential growth". However, the introductory statement is not a short document (the average statement in our sample has more than 1,300 words) and the standardization of the language used is far from perfect (the use of key words changes over time and standardization is not necessarily applied consistently to all sections). As a consequence, the coding of policy intentions is based on our reading of the full statement.

An important advantage of extracting from the introductory statements not only the ECB's aggregate policy intentions but also its intentions based on its disaggregated analyses of developments regarding price stability, the real economy, and the monetary sector is that it highlights potential tensions between subcategories and allows exploring the ECB's (possibly changing) way of dealing with these tensions. Take, for instance, the press conference of February $4^{\text {th }}, 1999$. While the Governing Council states that there are no "significant upward or downward pressures on prices in the short term", the information concerning the real economy suggests "downward risks for output growth", while the growth of credit causes some concern and therefore has to be "carefully monitored". So by comparing the information on the various subcategories with the overall monetary policy stance - based on the overall index and actual interest rate decisions taken - we are able to examine the role of money in the way the ECB communicates its policy intentions. Table 2 (upper panel) shows the correlation amongst the various indexes. An interesting message is that the correlation of the average monetary indicator with the other subindicators and the indicator of the overall policy stance is relatively low as compared to the subindexes based on the ECB's comments on price stability and the real sector. 
Table 2: Summary statistics of our indicators

\begin{tabular}{|c|c|c|c|c|}
\hline & \multicolumn{4}{|c|}{ Correlation matrix of averages: } \\
\hline & $\begin{array}{c}\text { Overall policy } \\
\text { stance }\end{array}$ & $\begin{array}{c}\text { Price stability } \\
\text { stance }\end{array}$ & $\begin{array}{c}\text { Real sector } \\
\text { stance }\end{array}$ & $\begin{array}{c}\text { Monetary sector } \\
\text { stance }\end{array}$ \\
\hline \multirow{7}{*}{\begin{tabular}{|l} 
Overall policy stance \\
Price stability stance \\
Real sector stance \\
Monetary sector stance \\
\end{tabular}} & \multirow[t]{4}{*}{1.00} & 0.92 & 0.95 & 0.58 \\
\hline & & \multirow{3}{*}{1.00} & 0.86 & 0.60 \\
\hline & & & \multirow{2}{*}{1.00} & \multirow{2}{*}{$\begin{array}{l}0.55 \\
1.00\end{array}$} \\
\hline & & & & \\
\hline & \multicolumn{4}{|c|}{ Correlation matrix of teams: } \\
\hline & \multicolumn{4}{|c|}{ Averages } \\
\hline & $\begin{array}{c}\text { Overall policy } \\
\text { stance }\end{array}$ & $\begin{array}{c}\text { Price stability } \\
\text { stance }\end{array}$ & $\begin{array}{c}\text { Real sector } \\
\text { stance }\end{array}$ & $\begin{array}{c}\text { Monetary sector } \\
\text { stance }\end{array}$ \\
\hline Team 1 & 0.92 & 0.86 & 0.92 & 0.89 \\
\hline Team 2 & 0.95 & 0.92 & 0.93 & 0.75 \\
\hline Team 3 & 0.94 & 0.85 & 0.97 & 0.84 \\
\hline
\end{tabular}

Note: The upper panel reports results for the "average" indicators as used in the remainder of the paper. The term average means that each of these indicators is computed as the mean of three independently generated indicators. The latter are based on the work of three research teams ("Team 1", "Team 2", and "Team 3"). The lower panel shows the correlation of the "average" indicators with the team-based indicators.

Communication is not a one-way street, and the empirical analysis has to control for differences in perception. To limit the influence of individual idiosyncrasies in this regard, the scaling of the overall and disaggregated policy stances communicated by the ECB was done by three different teams that operated independently from one another. Examples for the scores of the teams are shown behind the statements in Table 1. The average (or consensus) score of the teams is used in the empirical analyses. ${ }^{9}$. Table 2, in addition to showing the correlation amongst the various average indexes, also shows the correlation of the coding of the various teams with these averages (lower panel). The first notable finding here is that, in general, the team-based indicators move more or less in sync with the averages. Interestingly, however, the correlation of the monetary indicators for each of the teams and the final average monetary indicator are relatively low. Apparently, the monetary part in the introductory statements leads to the greatest variation in the assessment among the teams. Apparently, the message send by the Governing Council regarding its policy stance is somewhat less precise when it comes to the monetary sector.

\footnotetext{
${ }^{9}$ We have also experimented with other ways of aggregating the team scores, like the first principal component, the median, an average of standardized series, etc. The qualitative results are by no means affected by this.
} 


\section{The importance of money: word count}

In a first attempt to capture some of the information contained in the introductory statements, we conducted a simple word count. In particular, we identified, grouped, and counted words in full sentences occurring at any point in the introductory statement addressing a number of key issues. The first group contains statements referring to price developments, the second group of statements refers to the state of the real economy, the third to the monetary sector, and the fourth to a variety of other topics with some relevance to monetary policy, including exchange rate developments, the financial sector, or issues related to fiscal policy. ${ }^{10}$ A residual group, which we will ignore from now onwards, consists of words related to organizational issues. Figure 1 presents the distribution of words among our four groups for all 68 introductory statements during the 1999-2004 period and Table 3 provides a number of summary statistics.

\section{Figure 1: Relative number of words per topic}

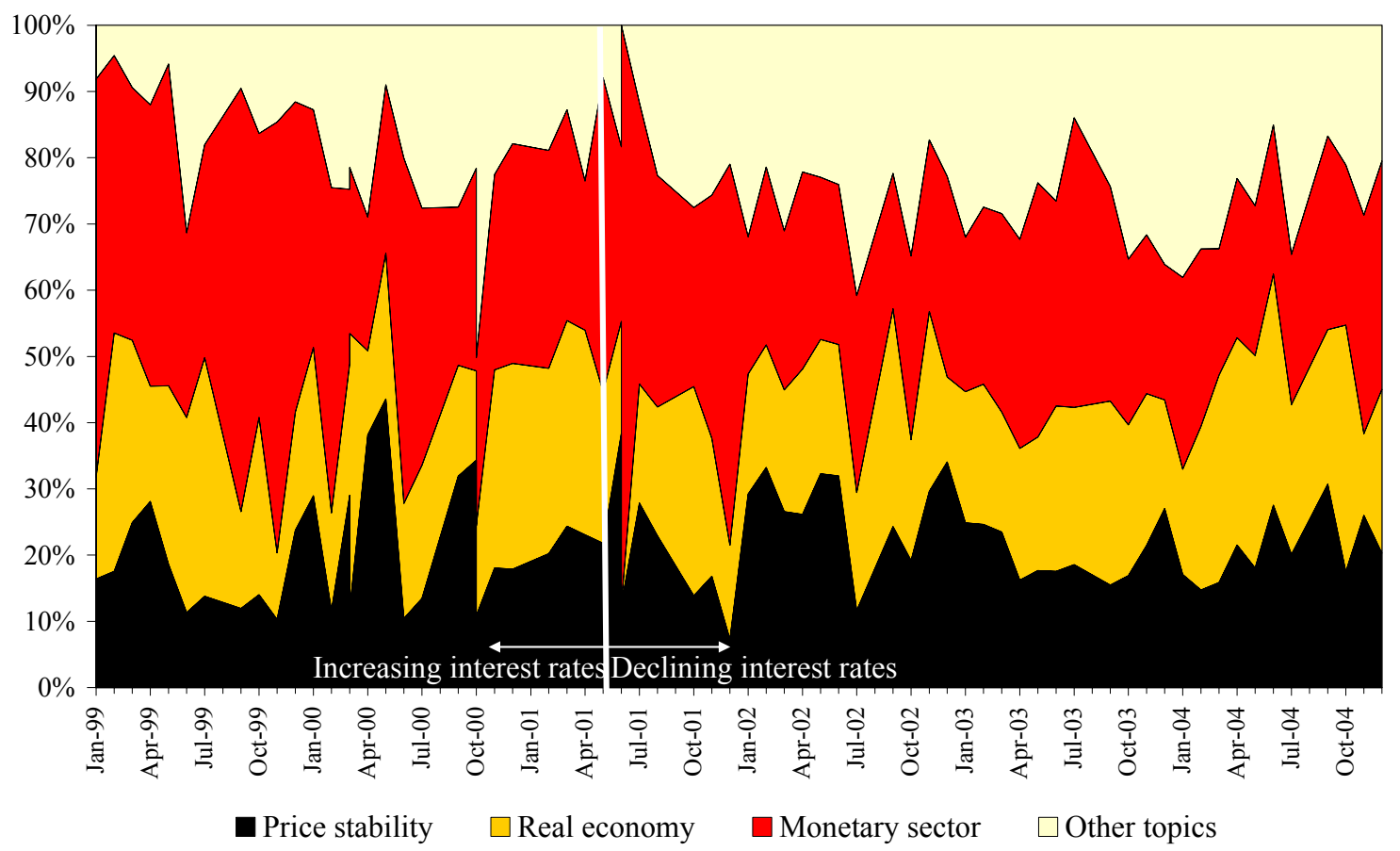

\footnotetext{
${ }^{10}$ As these other topics are not discussed on a continuous basis, it is not possible to construct policy stance measures on these (as we did with price developments, the real economy, and the monetary sector).
} 
Table 3: Word count analysis

\begin{tabular}{|c|c|c|c|c|c|c|}
\hline \multirow[b]{2}{*}{ Share of words on: } & \multicolumn{3}{|c|}{ Sample averages } & \multirow{2}{*}{$\begin{array}{l}\text { Equal mean } \\
\text { p-value }\end{array}$} & \multicolumn{2}{|c|}{ Threshold test } \\
\hline & Full sample & $<$ May-01 & $\geq$ May-01 & & Opt.date & $p$-value \\
\hline price stability & $21.6 \%$ & $20.7 \%$ & $22.3 \%$ & $42.3 \%$ & 2-Dec-99 & $40.3 \%$ \\
\hline real economy & $22.4 \%$ & $23.1 \%$ & $21.9 \%$ & $52.8 \%$ & 8-Jan-04 & $27.5 \%$ \\
\hline monetary sector & $33.4 \%$ & $37.5 \%$ & $30.7 \%$ & $2.9 \%$ & 6-Dec-01 & $0.0 \%$ \\
\hline other topics & $22.6 \%$ & $18.7 \%$ & $25.1 \%$ & $0.5 \%$ & 5-Jul-01 & $0.0 \%$ \\
\hline
\end{tabular}

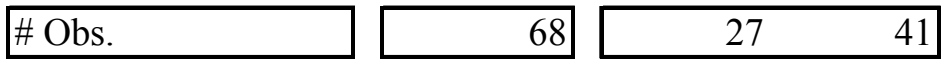

Note: p-values are reported for the Andrew and Ploberger (1994) test using Hansen's (1997) approximations.

It follows from Figure 1 and Table 3 that the weight allocated to the subjects of price stability, real economy, and other topics in the introductory statements is roughly equal, about 22-23 percent each. The monetary sector was given somewhat broader coverage in the range of 33 percent. However, this does not imply that the monetary analysis is more important than the economic analysis, as the latter relies on information on price developments and developments in the real economy. A second observation is that the proportion of words allocated to the monetary sector has decreased over time.

It has recently been argued in the literature that a central bank analyzes the economy in an asymmetric way over the business cycle, i.e. during periods of monetary tightening particular elements - like price stability or the real economy - might be given a different weight than during periods of monetary loosening. For instance, Cukierman (2000) argues that central bankers are not completely insensitive to social and political pressure and therefore more inclined to offsetting positive output gaps than negative ones for a given level of inflation. ${ }^{11}$ Goodhart (1998) argues that central banks that need to build up reputation (like the ECB) might show a precautionary demand for low inflation, i.e. would rather have inflation below than above target, everything else being equal. ${ }^{12}$ Therefore, we split the sample in two parts. In the first half of the sample, i.e. up to April 2001, the interest rates as set by the ECB were on the rise, whereas in the second half they were falling. Splitting the sample in April/May 2001, we note that monetary issues dominated before 2001 (at about 38 percent of the word count for the four groups selected) but fell to significantly lower levels (about 31 percent) thereafter. The associated gains occurred mostly in the other topics category. ${ }^{13}$ With respect to the monetary sector and other topics we cannot reject that there is a break between April and May 2001.

\footnotetext{
${ }^{11}$ See also Gerlach (2003) for a formal analysis.

${ }^{12}$ See Aguiar and Martins (2005), Ruge-Murcia (2003a,b) and Cukierman and Gerlach (2003) for empirical tests. Cukierman and Muscatelli (2002) build a model that gives a theoretical foundation for both a larger weight on inflation and a larger weight on output: If the central bank has to build up reputation, they put more weight on price stability to keep inflation expectations low. If the central bank has already built up enough reputation, the precautionary demand for economic expansions rises.

${ }^{13}$ Within the group of other topics there have been some clear shifts across time. Whereas comments on the financial sector almost completely disappeared and exchange rate issues also got less attention, other policy and especially fiscal policy issues more than compensated for this after May 2001.
} 
It is interesting to more precisely pinpoint structural changes in the ECB's communication, in particular with respect to the role of monetary analysis. To that end we perform the Andrews and Ploberger (1994) structural break tests for a linear regression, with p-values using Hansen's (1997) approximations. ${ }^{14}$ The optimal threshold date for the monetary sector is only shortly after May 2001, i.e. in December. The optimal break for the other topics category is July 2001 and hence occurs almost around the same time. For the other two components we do not find a significant threshold anywhere in our data. However, the threshold tests contained in Figure 2 suggest that the significance of the decrease in the weight monetary issues received is fairly independent of the precise date chosen.

Figure 2: Threshold break test result for the monetary sector using words count data

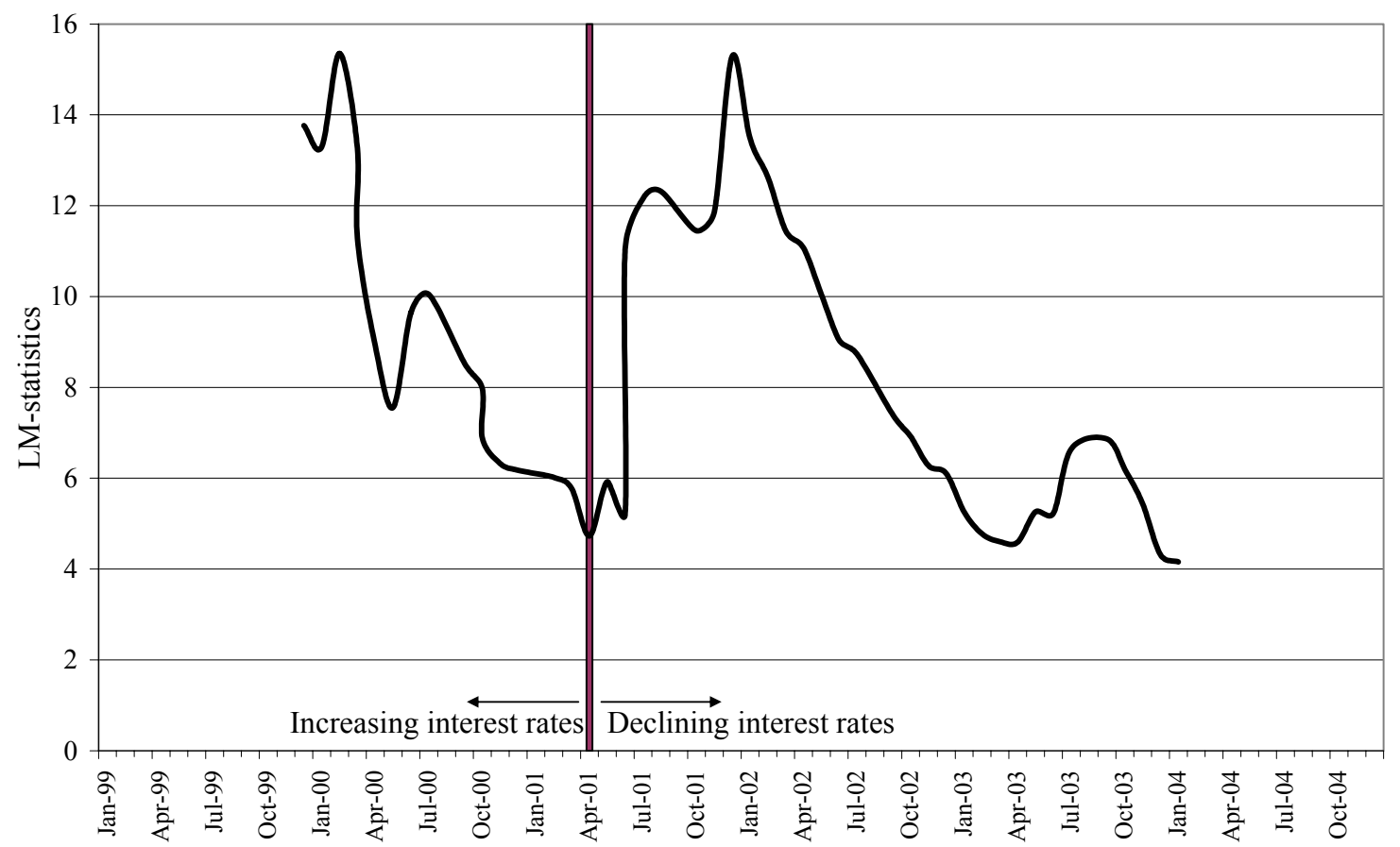

Note: Approximately every test statistic above 6 rejects the null hypothesis of no break at that particular date.

While these results are interesting, fewer words do not necessarily imply less importance when it comes to influencing the ECB's policy intentions as communicated through the introductory statements. For instance, the statements might include fewer words allocated to the monetary sector during the post-2001 period because the policy implications of the analysis stemming from the monetary sector became clearer. In the following section we will therefore analyse the role of money in the ECB monetary policy strategy using the indicators as outlined in Section 2.

\footnotetext{
${ }^{14}$ A series of LM statistics are generated for breaks at each of the points in the middle range of the data set. The break generating the highest LM statistic is the most likely candidate. To approximate p-values, it uses an exponentially weighted average of these LM statistics.
} 


\section{The importance of money: analysis of our indicators}

The stance-indicators we constructed on the basis of the press conferences can each take on values between -3 (strong inclination to lower interest rates) and +3 (strong inclination to increase interest rates). Three topics return in each statement: developments in the monetary sector, price developments, and developments in the real economy. Besides looking at the overall policy intention, we will also look at these three underlying components.

Figure 3: Indexes on monetary policy stance/inclination/leaning

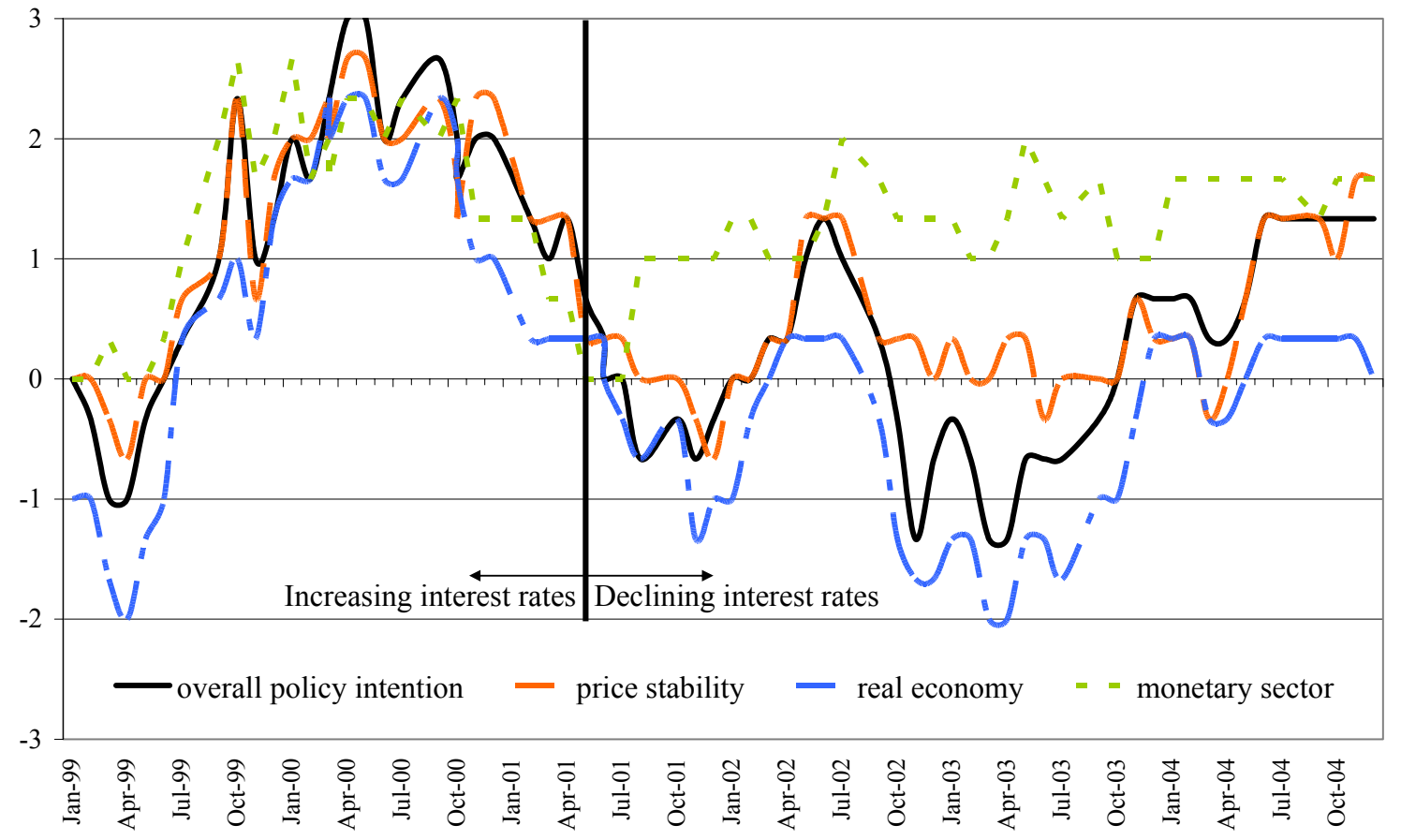

As Figure 3 shows, the three sub indicators and our overall measure of policy intention coincide pretty much up until the summer of 2001 (July $\left.5^{\text {th }}, 2001\right)$, the time at which all indicators took a more or less neutral position. After that our indicator for the monetary sector departs from the other indicators, to maintain a high and relatively stable value ever since. Even when putting the monetary sector aside, price developments and developments of the real economy as described in the press statements are clearly more out of line after the summer of 2001 than before. What the data in Figure 3 furthermore suggest is that the overall policy stance leaned more on the assessment of price developments in the early half and at the very end of our sample, whereas the real economy appeared to set the tone during the second half of 2002 up until the end of 2003.

As the overall policy indicator has not been directly derived from the three underlying components, it is possible to test what the implicit weights are that the ECB assigns to these sub indicators. Given that all indicators are defined over the interval ( -3 , 3 ) where the value zero represents the neutral position for all, the regressions do not 
contain a constant. Hence, we assume that the average overall policy position is neutral once we have corrected for the underlying three sectors. ${ }^{15}$

Table 4: Regression results explaining overall policy intention by underlying components

\begin{tabular}{|c|c|c|c|c|c|}
\hline$(1)$ & (2) & (3) & (4) & (5) & (6) \\
\hline \multirow{4}{*}{$\begin{array}{r}0.932 \\
1.09\end{array}$} & 0.942 & 0.953 & 0.957 & 0.957 & 0.957 \\
\hline & & 1.71 & & & \\
\hline & 10.23 & & 1.13 & 1.10 & 1.49 \\
\hline & 0.00 & & 0.29 & 0.29 & 0.22 \\
\hline \multirow[t]{2}{*}{68} & 67 & 68 & 67 & 67 & 67 \\
\hline & & 0.00 & 0.00 & 0.00 & 0.00 \\
\hline
\end{tabular}

\begin{tabular}{l} 
adj. $\mathrm{R}^{2}$ \\
Durbin-Watson \\
LM-test \\
Significance LM-test \\
\# Obs \\
Chow-test (sign.level) \\
\hline
\end{tabular}

coefficients up to April 2001

price stability
real economy
monetary sector
Lagged overall policy intention

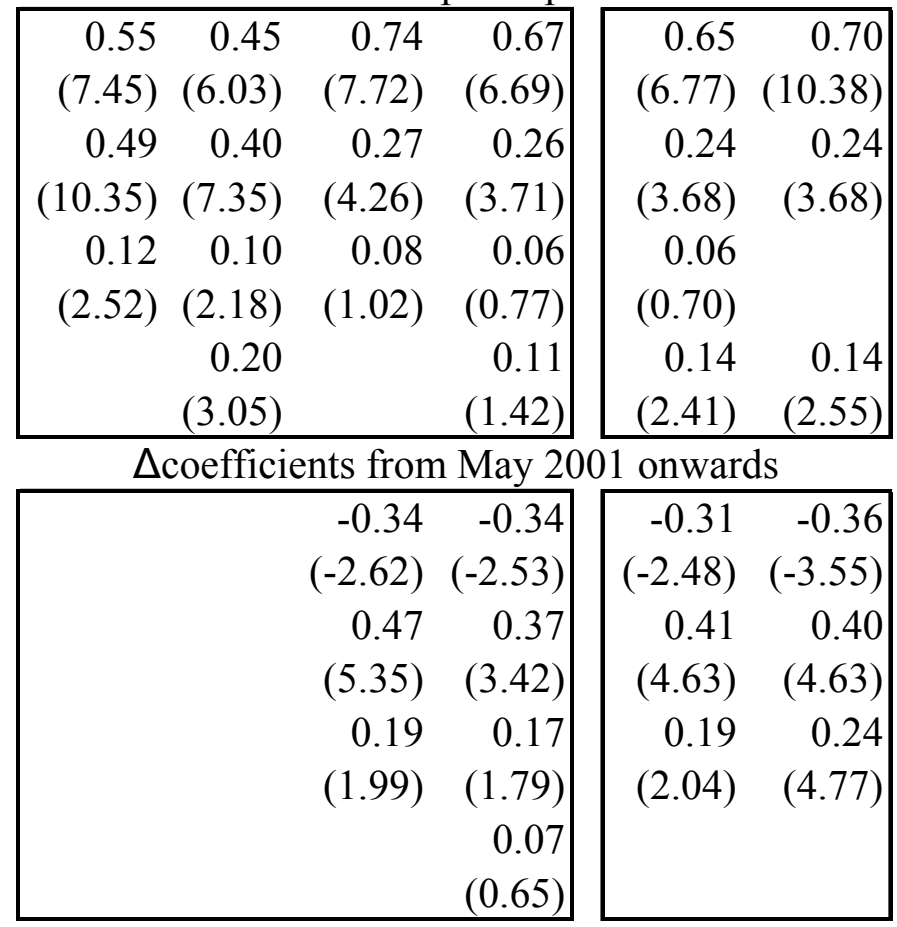

Notes: t-statistics are in parentheses. The Chow test is checking joint significance of the coefficients in the bottom part of the table, i.e. testing whether we can reject the null hypothesis of having no break.

Column (1) of Table 4 reveals that over the entire period, price developments as well as developments in the real economy were given the largest weights in judging the overall situation. Monetary developments were clearly given a much smaller weight. The

\footnotetext{
${ }^{15}$ The only plausible reason for having a constant in the regressions would be if there would a fourth component relevant for the ECB which on average does not have a neutral stance. Hence, we assume here that all other determinants of the overall policy stance have on average a value of zero and are therefore part of the residual. We have also run the regressions including a constant; it turned out that it is in most situations insignificant and does not alter our qualitative conclusions.
} 
Durbin-Watson statistic shows that there is positive autocorrelation in the residuals of this first equation. A potential reason might be that previous press statements echo on to the subsequent one. To test for this policy inertia effect we include the lagged dependent variable in the Column (2) of Table 4. The estimated coefficient is significant; however, the estimated size of this effect is far less than for both the coefficients of price stability and the real economy. ${ }^{16}$ Note furthermore, that the general LM test of Godfrey (1978) and Breusch (1978) is highly significant, still indicating problems with respect to the residuals and therefore the specification.

As Figure 3 suggests that the implicit weights given by the central bank might have changed over time, we allow the econometric model to differentiate the coefficients of interest across sub periods. A likely candidate is the turning point in the interest rate cycle in May 2001, but none of the following results depend on the precise timing of the break. Columns (3) and (4) of Table 4 redo the previous two specifications, taking this break into account. The estimated changes in coefficients in the second part of the sample along with their test statistics are reported in the lower half of the table.

A first result is that the problems associated with the residuals presented in columns (1) and (2) of Table 4 seem indeed to be related to a structural break in the underlying data. Both the Durbin-Watson in Column (3) and the LM statistic in Column (4) become insignificant once we allow for a structural break between April and May 2001. The Chow test indicates that the changes in the coefficients after the break are jointly highly significant. Before the break, price developments were clearly the most important determinant of the ECB's policy stance, whereas after the break that role was taken over by developments in the real economy. As there does not appear to be a significant change in the policy inertia parameter over the two periods, we presume that this kind of inertia is not sample dependent in Column (5) of Table 4. Interestingly, developments in the monetary sector did not play a significant role before the break, while after the break its impact is significant, albeit at relatively modest levels. Our preferred specification is shown in Column (6) of Table 4 in which the weight on the monetary sector in the first half of the sample is set equal to zero. This merely strengthens the previous findings.

The evidence suggests that, in contrast to what many observers argue, the role of the monetary analysis - as represented in the ECB President's introductory statement at the monthly press conference - has not been reduced in importance in the second half of our sample period. The opposite appears to be more likely. Still, money only plays a relatively minor role in determining the ECB's policy stance. Even post May 2001, in our preferred specification, the coefficient measuring the importance of the monetary sector in determining the ECB's overall monetary policy stance is only somewhat more than a third of the coefficient for the real sector and little more than two-thirds of the coefficient for the price sector. ${ }^{17}$

\footnotetext{
${ }^{16}$ Including lagged values of the three sub indicators instead results in insignificant estimate for all additional coefficients. Hence, once contemporaneous values of the three sectors are included, their previous values do not add aditional information.

${ }^{17}$ See column (6) in Table 4. As mentioned above, the coefficient for the monetary sector is zero before May 2001. To compare coefficients in the second period, the estimated coefficients in the middle and lower panels of Table 4 have to be added. The quantitative-economic impact of the monetary indicator is even smaller than what the relative size of the coefficient suggests, as the monetary indicator is less volatile than the price and real indicator during this part of the sample period.
} 
So far, the threshold of April 2001 has been selected on theoretical grounds-but does this also coincide with what the data tell us? Figure 4 shows the results when testing for the date of a threshold break in our regression shown in Column (2) of Table 4 using the Andrews and Ploberger (1994) approach. The highest test statistic prevails for July $4^{\text {th }}, 2002$. However, the figure also clearly shows that during the period October 2000 and October 2002, the test statistic takes on high values (which are always significant on a 1 percent level). Hence, it is difficult for the data to assess the exact threshold point. However, there clearly is a break in the weights the empirical model allocates to the three sectoral indicators and the most likely time window for this break includes the turning point in the ECB's interest rate cycle, that is, May 2001. In contrast, a break in May 2003 - the date at which the ECB Governing Council announced some changes in their way of communicating the two pillars - appears to be less likely.

Figure 4: Threshold break test results explaining overall policy intention

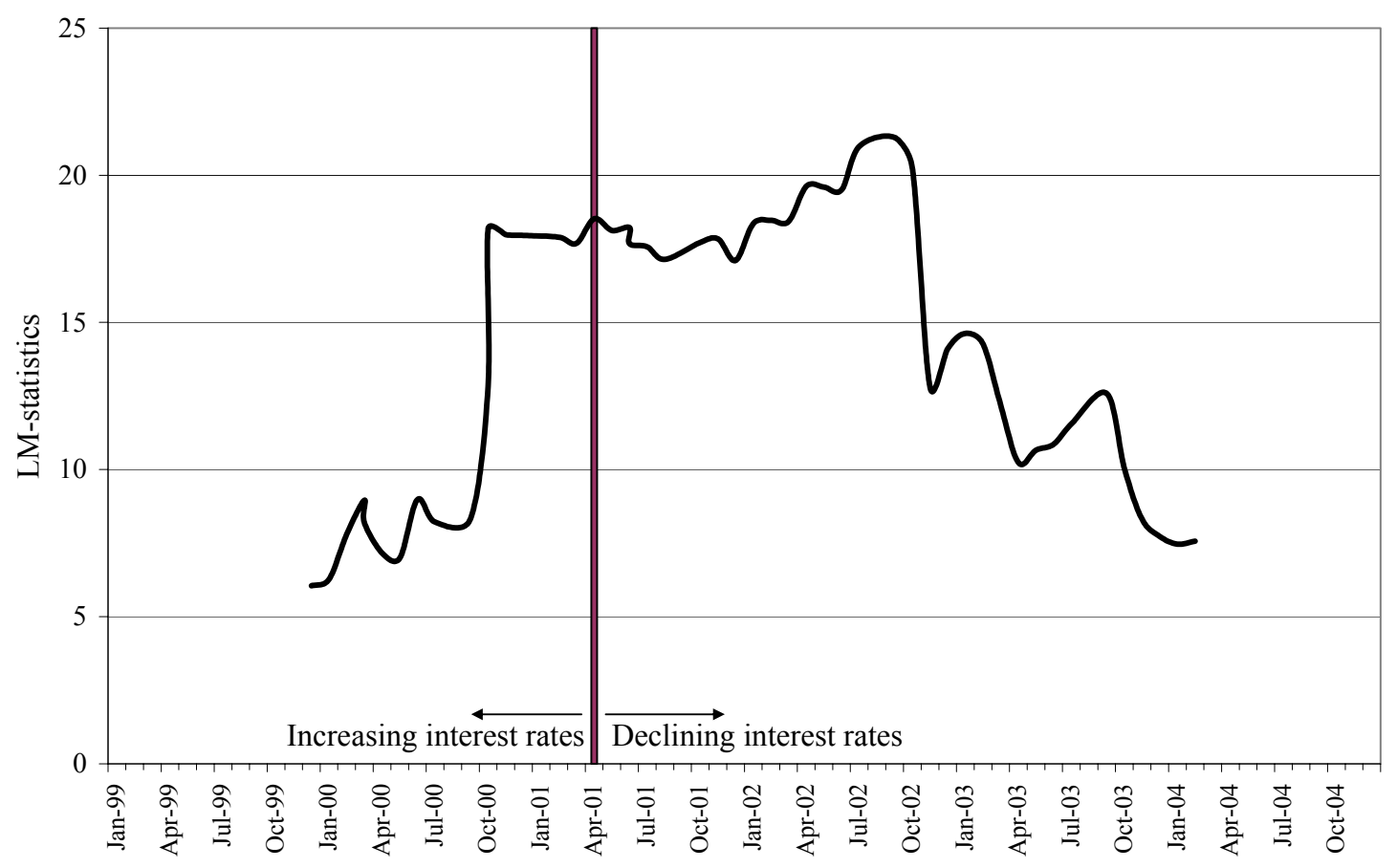

\section{Are the Deeds Following the Words?}

Our analysis of the previous section suggests that the monetary pillar has played a minor role in determining the overall monetary policy stance according to our overall policy indicator. One may, of course, argue that despite the theoretical arguments put forward in section 2, it is not words but deeds that count. Did the ECB follow up its communication by action? To answer this question, we have first to decide whether to look at all ECB policy decisions over the sample period under consideration, i.e. 108 meetings of the General Council, or to focus only on the 68 meetings that were followed by a press 
conference with an introductory statement of the President agreed upon by the Governing Council. Because the decision to hold a press conference and/or prepare an introductory statement is in itself part of the ECB's communication strategy, using the full 108 meeting data set seems to be called for. However, the results reported below do not change substantially if we constrain the analysis to the 68 observations for which introductory statements are available.

In Table 5 we regress the ECB's main refinancing rate (MRR) on our three measures of communicated monetary policy, i.e. price developments, real economy and monetary sector. In the left part of that table, where we explain the actual level of the MRR, we also include a constant, the policy rate as it is shortly before the Governing Council meeting, and its change as made in the previous meeting. ${ }^{18}$ In this way our Taylor-rule type of equation allows for the usual policy inertia. As it might be argued that the policy rate resembles a non-stationary process, we also show-in the middle part of the table - the results using the first-difference of the main refinancing rate as our dependent variable. Interest rate decisions do have a rather discrete character; in practice the MRR only changes by steps of 25 basis points or 50 basis points. To econometrically cope with this, the right part of Table 5 reports results using an ordered probit estimator. ${ }^{19}$ Note that overall the results do not depend upon these three distinct ways in which we set up our model.

It is generally agreed that communication not only serves to justify actions taken, but also to prepare markets for upcoming changes. Hence, communication is likely to be forward-looking. For that reason, we include besides the contemporaneous values of our press release indicators also their lagged ones.

Furthermore, given the results in the previous sections, we expect a significant break during our sample. As before, we start by assuming this break to potentially take place in May 2001. We will subsequently test for this.

\footnotetext{
${ }^{18}$ The latter we include to remove remaining negative autocorrelation from the regression. The qualitative results are not affected by this in any way. We, therefore, will not comment on this variable.

${ }^{19}$ Note in this case, the coefficients cannot be interpreted in the usual way; they depend upon the scale of the cut-off points.
} 
Table 5: Regression results explaining which components used in the press statements drive actual interest rate decisions

\begin{tabular}{|ccc|}
\hline \multicolumn{3}{|c|}{ MRR (OLS) } \\
$(1)$ & (2) & (3) \\
\hline
\end{tabular}

\begin{tabular}{|lll|}
\hline \multicolumn{3}{|c|}{$\triangle \mathrm{MRR}($ OLS) } \\
$(4)$ & $(5)$ & $(6)$ \\
\hline
\end{tabular}
$\triangle \mathrm{MRR}$ (ordered probit)

\begin{tabular}{|l|}
\hline adj./pseudo $\mathrm{R}^{2}$ \\
Durbin-Watson \\
LM-test \\
Sign. LM-test \\
\# Obs \\
Chow-test (sign.) \\
\begin{tabular}{|l} 
Constant \\
MMR before \\
meeting \\
Previous $\Delta \mathrm{MRR}$ \\
Price stability \\
Lagged price \\
stability \\
Real economy \\
Lagged real \\
economy \\
Monetary sector \\
Lagged monetary \\
sector
\end{tabular} \\
\hline
\end{tabular}

$\left.\begin{array}{|rrr}\hline 0.984 & 0.985 & 0.985 \\ 2.18 & 2.21 & 2.16 \\ 4.14 & 4.81 & 3.22 \\ 0.04 & 0.03 & 0.07 \\ 107 & 107 & 107 \\ 0.03 & 0.00 & 0.00\end{array}\right]\left[\begin{array}{rrr}0.290 & 0.311 & 0.309 \\ 2.11 & 2.12 & 2.10 \\ 1.77 & 1.86 & 1.39 \\ 0.18 & 0.17 & 0.24 \\ 107 & 107 & 107 \\ 0.01 & 0.00 & 0.00\end{array} \mid \begin{array}{rrrr|}0.615 & 0.599 & 0.538 \\ & & \\ & & & \\ 107 & 107 & 107 \\ 0.16 & 0.00 & 0.00 \\ \hline\end{array}\right.$

coefficients up to April 2001

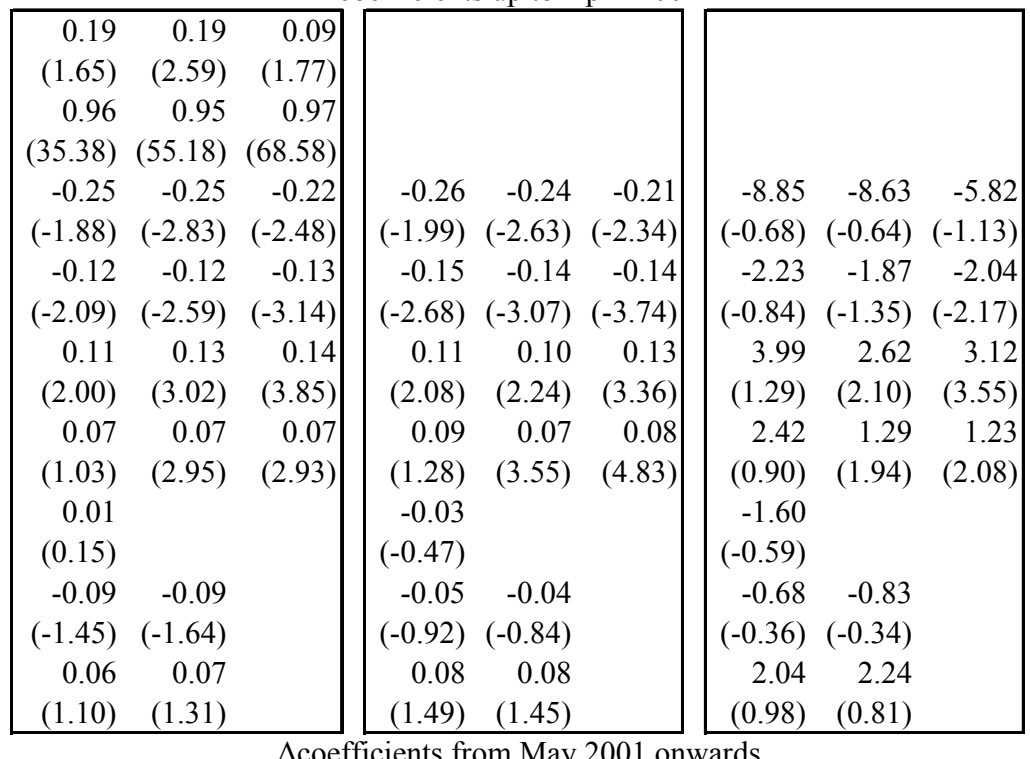

\begin{tabular}{|l|} 
Constant \\
MMR before \\
meeting \\
Previous $\triangle \mathrm{MRR}$ \\
Price stability \\
Lagged price \\
stability \\
Real economy \\
Lagged real \\
economy \\
Monetary sector \\
Lagged monetary \\
sector
\end{tabular}

$\left.\begin{array}{|rrr|}\hline 0.02 & & \\ (0.09) & & \\ -0.01 & & \\ (-0.33) & & \\ -0.01 & & \\ (-0.04) & & \\ 0.22 & 0.21 & 0.22 \\ (2.74) & (3.33) & (3.82) \\ -0.19 & -0.21 & -0.25 \\ (-2.41) & (-3.41) & (-4.29) \\ 0.01 & & \\ (0.08) & & \\ -0.02 & & \\ (-0.28) & & \\ 0.06 & 0.06 & \\ (0.72) & (0.84) & \\ -0.10 & -0.11 & \\ (-1.20) & (-1.40) & \end{array}\right]\left[\begin{array}{rrr}0.06 & & \\ (0.31) & & \\ 0.26 & 0.26 & 0.25 \\ (3.42) & (4.10) & (4.23) \\ -0.22 & -0.21 & -0.26 \\ (-2.92) & (-3.25) & (-4.28) \\ 0.02 & & \\ (0.22) & & \\ 0.00 & & \\ (-0.00) & & \\ 0.03 & 0.03 & \\ (0.41) & (0.35) & \\ -0.09 & -0.09 & \\ (-1.08) & (-1.14) & \\ -2.06 & & \\ (-0.00) & & \\ 7.35 & 6.56 & 5.52 \\ (1.56) & (2.47) & (2.82) \\ -7.35 & -5.74 & -5.82 \\ -1.78) & (-3.12) & (-3.99) \\ -0.95 & & \\ -0.28) & & \\ 1.85 & & \\ (0.56) & & \\ 0.57 & 0.36 & \\ (0.16) & (0.12) & \\ -1.19 & -1.62 & \\ (-0.29) & (-0.50) & \\ \hline\end{array}\right.$

Notes: t-statistics are in parentheses. The Chow test is checking whether the coefficients in the bottom part of the table are jointly significant. The cut-off points for the order probit regression in Column (9) are -3.03 (between -0.5/-0.25), -2.62 (between -0.25/0), 5.25 (between 0/0.25), and 6.63 (between 0.25/0.5). 
All together this results in a rather comprehensive first model which is presented in Columns (1), (4) and (7) of Table 5. The lower part of the table reports the change in the coefficients as they have been estimated for the post-May 2001 period; the upper part shows the results for the period until our break date. Except for the ordered probit model, the Chow tests report clear evidence of a significant break in May 2001. However, it is also clear that a number of estimated coefficients hardly differ from zero. Dropping insignificant variables other than our main variables of interest, i.e. indicators related to the monetary sector, we arrive at the specifications in Columns (2), (5) and (8). This improves the overall fit and makes the break even more pronounced (including in the ordered probit model) without affecting the qualitative results.

A first finding from Table 5 is that the contemporaneous version of our real economy measure is highly significant in explaining developments in the main refinancing rate. This coefficient is stable across the periods and its lagged version has no significant impact. A possible interpretation is that the ECB is using developments in the real economy to explain why the main refinancing rate has been set at its present level. Its role in preparing the markets for upcoming changes appears all but negligible.

This does not hold for price developments in the first part of our sample. Up until April 2001, a higher value in the previous press release increases the likelihood of having a subsequent policy rate increase. As the sum of the contemporaneous and lagged coefficients almost equals zero, this effect disappears at the next meeting. Hence, a communicated increase in the ECB's propensity to raise interest rates due to price increases is more likely to be followed by an increase in the ECB's main refinancing rate one meeting ahead than during the meeting after which it is communicated. In other words, communication with respect to price developments seems to be forward-looking. Note, however, that in the later part of the sample the importance of the contemporaneous coefficient increases substantially. The reverse holds for the lagged variable. In other words, after 2001 the ECB seems to have been more inclined to use communication with respect to price developments to explain current interest rate decisions than preparing markets for upcoming ones.

What role did money play in the ECB interest rate decisions? All our results hardly show any role for money in actual interest rate decisions. At best one could argue (using a 20 percent significance level) that - as with price developments - in the preMay-2001 period it was used in a forward-looking manner, i.e. to prepare markets for upcoming increases in the main refinancing rate. From then onwards, however, both contemporaneous and lagged coefficients for our monetary sector indicator become indistinguishable from zero at any plausible significance level. Columns (3), (6) and (9) report the results in case variables that are insignificant at the 10 percent level are one at a time removed from the specification. ${ }^{20}$ This leads to the removal of all monetary sector indicators. In other words, when it comes to interest rate decisions our results suggest that money does not matter.

\footnotetext{
${ }^{20}$ For ease of comparison we have left the previous change in the main refinancing rate in the ordered probit specification. As noted in footnote 18, this does not affect our conclusions.
} 
Figure 5: Threshold break test results explaining interest rate decisions

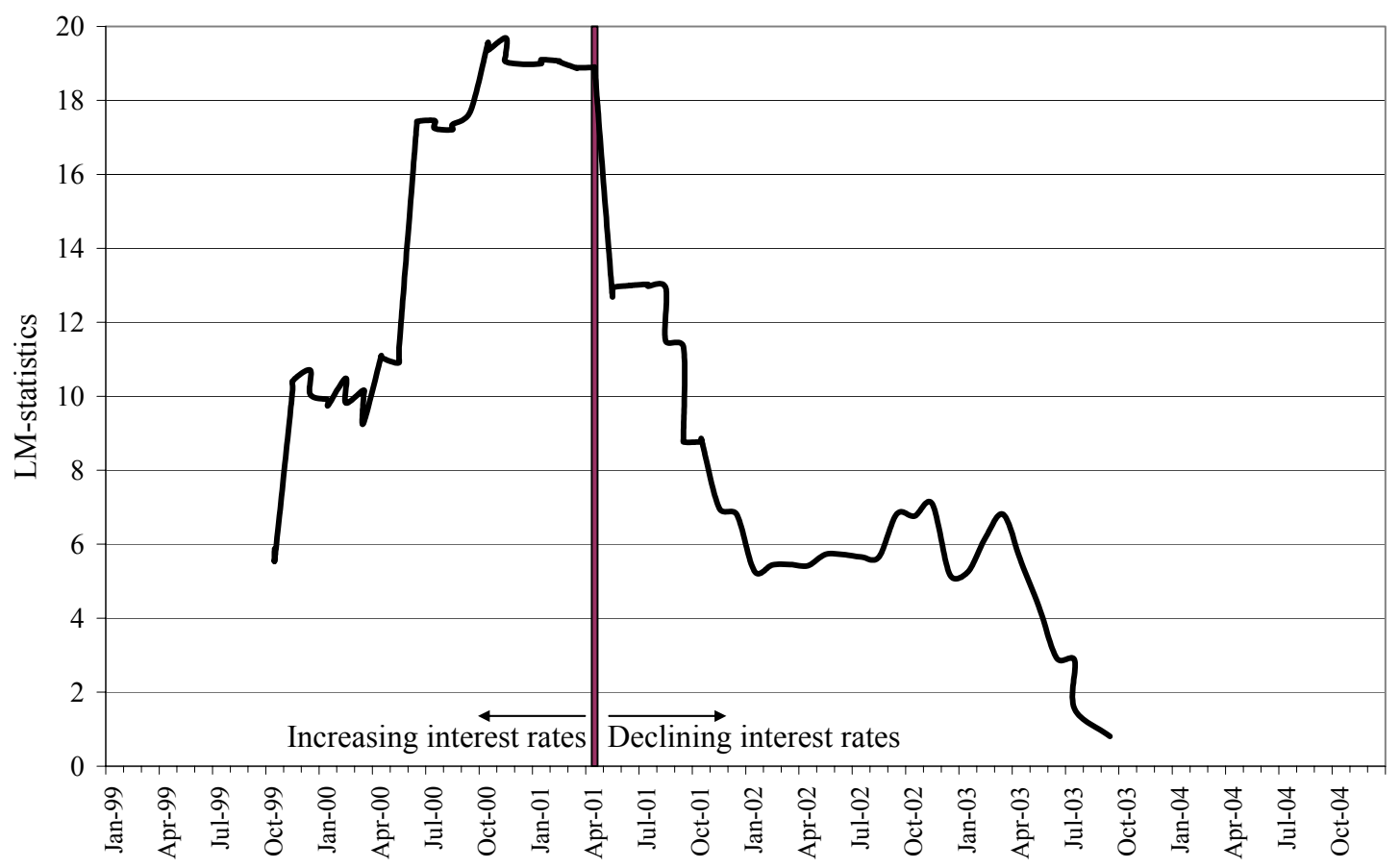

As before, the threshold of May 2001 has been selected on theoretical grounds. Figure 5 reports the results when testing for the date of a threshold break in our regression shown in Column (5) of Table 5. This time, the highest test statistic prevails for November $2^{\text {nd }}, 2000$. Clearer than before, the figure shows that a break is most likely to have occurred between October/November 2000 and April/May 2001. On the other hand, a break in April/May 2003 - the time where the ECB Governing Council changed their way of communicated the two pillar strategy - appears to be rather unlikely.

\section{Concluding Remarks}

This paper examines the role of money in the monetary policy strategy of the ECB based on its policy intentions as communicated in the introductory statement of the ECB President at the press conference following Governing Council meetings. We construct an indicator of the ECB's overall policy intention stemming from its aggregated view of the economy. In addition, we measure the policy implications of the ECB's views on certain disaggregated economic developments coinciding with the "economic analysis" (including the real sector and price developments) and the "monetary analysis". Our data set includes a total of 68 introductory statements extending from January 1999 to December 2004.

In a first step we perform a simple word count which yields two main results. First, the relative share of words devoted to the subjects of price developments, real economy, and other topics in the introductory statements is about 22-23 percent each, while the monetary sector was given somewhat broader coverage in the range of 33 percent. Second, over time, the relative amount of words devoted to the monetary 
analysis in the introductory statement decreases. The question is whether this also suggests a decrease in relative importance when it comes to the communicated ECB policy intentions.

Our analysis of indicators of the ECB's overall policy stance suggests that developments in the monetary sector did not play a significant role most of the time. There are, however, indications for a change that contrasts with the simple word-count exercise and with the view of many observers: while monetary analysis was never quite as important in determining the ECB's overall policy intentions as price developments or the real sector, our results suggest that the ECB has come to rely somewhat more on monetary developments over time. In particular, we find evidence for a structural break (after which monetary analysis gained in importance) in early 2001, at the upper turning point of the interest cycle. There is little indication of a break in May 2003 when the ECB presented the outcomes of its evaluations of its monetary policy strategy and changed the presentation of the introductory statement.

Moving from words to deeds, the monetary sector seems to play an even smaller role. We show that ECB interest rate decisions are barely influenced by its monetarysector based policy intentions. Policy intentions based on developments in the real economy and, to a smaller degree, on price developments, are the main factors explaining actual policy changes. This holds throughout the sample. To the extent that there is evidence of an influence of monetary-sector based policy intentions at all, it is limited to the first part of the sample.

A final result is that, before early 2001, the communicated policy intentions were predominantly linked to future interest rate decisions, while, thereafter, they appear mainly related to contemporaneous policy decisions. This suggests a declining degree of forward-lookingness of communication. 


\section{References}

Aguiar, A. and M.M.F. Martins (2005), Testing for asymmetries in the preferences of the euro-area monetary policymaker, University of Porto, FEP Working Paper No. 182.

Andrews, D.W.K. and W. Ploberger (1994), Optimal Tests When a Nuisance Parameter is Present Only Under the Alternative, Econometrica, 62, 1383-1414.

Bernanke, B. (2004), Fedspeak. Remarks at the Meetings of the American Economic Association, San Diego, California, January 3, 2004, available at www.federalreserve.govboarddocs/speeches/2004/200401032/default.htm.

Blinder, A. S. (1998), Central Banking in Theory and Practice, Cambridge MA: MIT Press.

Blinder, A.S., C.A.E. Goodhart, P.M. Hildebrand, D.A. Lipton and C. Wyplosz (2001), How do central banks talk? Geneva Reports on the World Economy 3, ICMB and CEPR.

Breusch, T.S. (1978), Testing for autocorrelation in dynamic linear models, Australian Economic Papers, 17, 334-355.

Carstensen, K. and R. Colavecchio (2004), Did the Revision of the ECB Monetary Policy Strategy Affect the Reaction Function?, Kiel Working Paper No. 1221.

Cukierman, A. (2000), The inflation bias result revisited, Tel-Aviv University, Berglas School of Economics, mimeo.

Cukierman, A. and S. Gerlach (2003), The inflation bias revisited: Theory and some international evidence, Manchester School, 71 (5), 541-565.

Cukierman, A. and A. Muscatelli (2002), Do central banks have precautionary demands for expansions and for price stability?, CESifo Working Paper No. 764.

De Grauwe, P. (2003), The Central Bank That Has Missed the Point, Financial Times, May 13, 2003.

De Haan, J. and S.C.W. Eijffinger (2000), The democratic accountability of the European Central Bank: A comment on two fairy-tales, Journal of Common Market Studies 38(3), 393-407.

De Haan, J., S.C.W. Eijffinger and S. Waller (2005), The European Central Bank Credibility, Transparency, and Centralization, MIT Press, Cambridge (MA).

Ehrmann, M. and M. Fratzscher (2005), Central bank communication: different strategies, same effectiveness?, ECB Working Paper No. 488.

Fratzscher, M. (2004), Communication and exchange rate policy, ECB Working Paper No. 363.

Gerlach, S. (2003), Recession aversion, output and the Kydland-Prescott Barro-Gordon model, Economics Letters, 81 (3), 389-394.

Gerlach, S. (2004), The two pillars of the European Central Bank, Economic Policy, 19, 390-439.

Godfrey, L.G. (1978), Testing against general autorgressive and moving average error models when the regressors include lagged dependent variables, Econometrica, 46, 1293-1302.

Goodhart, C.A.E. (1998), Central bankers and uncertainty, LSE, Financial markets group Special Paper No. 106, October.

Hämäläinen, S. (2001), The ECB's Monetary Policy-Accountability, Transparency and Communication, Introduction at the Old Age, New Economy and Central Banking 
Conference, organized by CEPR/ESI and Suomen Pankki 14 September 2001, Helsinki.

Hansen, B.E. (1997), Approximate Asymptotic P-Values for Structural Change Tests, Journal of Business and Economic Statistics, 15, 60-67.

Heinemann, F. and K. Ullrich (2005), Does it Pay to Watch Central Bankers' Lips? The Information Content of ECB Wording, mimeo, Centre for European Economic Research (ZEW), Mannheim.

Issing, O. (2001), The Euro Area and the single monetary policy, Oesterreichische Nationalbank Working Paper No. 44.

Issing, O. (2005), Communication, Transparency, Accountability: Monetary Policy in the Twenty-First Century, Federal Reserve Bank of St. Louis Review 87, 65-83.

Jaeger, A. (2003), The ECB's Money Pillar: An Assessment, IMF Working Paper, No. $03 / 82$.

Jansen, D. and J. De Haan (2005a), Talking heads: the effects of ECB statements on the euro-dollar exchange rate, Journal of International Money and Finance, 24, 343-361.

Jansen, D. and J. De Haan (2005b), Look Who's Talking: ECB communication during the first years of EMU, International Journal of Finance and Economics, forthcoming.

Posen, A.S. (2003), Six practical views of central bank transparency, in P.Mitzen, ed., Central banks, monetary theory and policy: Essays in honour of Charles Goodhart, London: Edward Elgar.

Rosa, C. and G. Verga (2005), Is ECB Communication Effective? CEP Discussion Paper No. 682.

Ruge-Murcia, F.J. (2003a), Does the Barro-Gordon model explain the behavior of US inflation? A reexamination of the empirical evidence, Journal of Monetary Economics, 50 (6), 1375-1390.

Ruge-Marcia, F.J. (2003b), Inflation targeting under asymmetric preferences, Journal of Money, Credit, and Banking, 35 (5), 763-785.

Sims, G.T. and D. Wessel (2000), The European Central Bank can't master communication, The Wall Street Journal 27 April.

Svensson, L.E.O. (2003), In the Right Direction, But Not Enough: The Modification of the Monetary-Policy Strategy of the ECB, Briefing paper for the Committee on Economic and Monetary Affairs (ECON) of the European Parliament, www.princeton.edu/ $\sim$ svensson. 


\section{CESifo Working Paper Series}

(for full list see www.cesifo-group.de)

1589 Kazuo Ogawa, Elmer Sterken and Ichiro Tokutsu, Bank Control and the Number of Bank Relations of Japanese Firms, November 2005

1590 Bruno Parigi and Loriana Pelizzon, Diversification and Ownership Concentration, November 2005

1591 Claude Crampes, Carole Haritchabalet and Bruno Jullien, Advertising, Competition and Entry in Media Industries, November 2005

1592 Johannes Becker and Clemens Fuest, Optimal Tax Policy when Firms are Internationally Mobile, November 2005

1593 Jim Malley, Apostolis Philippopoulos and Ulrich Woitek, Electoral Uncertainty, Fiscal Policy and Macroeconomic Fluctuations, November 2005

1594 Assar Lindbeck, Sustainable Social Spending, November 2005

1595 Hartmut Egger and Udo Kreickemeier, International Fragmentation: Boon or Bane for Domestic Employment?, November 2005

1596 Martin Werding, Survivor Benefits and the Gender Tax Gap in Public Pension Schemes: Observations from Germany, November 2005

1597 Petra Geraats, Transparency of Monetary Policy: Theory and Practice, November 2005

1598 Christian Dustman and Francesca Fabbri, Gender and Ethnicity - Married Immigrants in Britain, November 2005

1599 M. Hashem Pesaran and Martin Weale, Survey Expectations, November 2005

1600 Ansgar Belke, Frank Baumgaertner, Friedrich Schneider and Ralph Setzer, The Different Extent of Privatisation Proceeds in EU Countries: A Preliminary Explanation Using a Public Choice Approach, November 2005

1601 Jan K. Brueckner, Fiscal Federalism and Economic Growth, November 2005

1602 Steven Brakman, Harry Garretsen and Charles van Marrewijk, Cross-Border Mergers and Acquisitions: On Revealed Comparative Advantage and Merger Waves, November 2005

1603 Erkki Koskela and Rune Stenbacka, Product Market Competition, Profit Sharing and Equilibrium Unemployment, November 2005

1604 Lutz Hendricks, How Important is Discount Rate Heterogeneity for Wealth Inequality?, November 2005 
1605 Kathleen M. Day and Stanley L. Winer, Policy-induced Internal Migration: An Empirical Investigation of the Canadian Case, November 2005

1606 Paul De Grauwe and Cláudia Costa Storti, Is Monetary Policy in the Eurozone less Effective than in the US?, November 2005

1607 Per Engström and Bertil Holmlund, Worker Absenteeism in Search Equilibrium, November 2005

1608 Daniele Checchi and Cecilia García-Peñalosa, Labour Market Institutions and the Personal Distribution of Income in the OECD, November 2005

1609 Kai A. Konrad and Wolfgang Leininger, The Generalized Stackelberg Equilibrium of the All-Pay Auction with Complete Information, November 2005

1610 Monika Buetler and Federica Teppa, Should you Take a Lump-Sum or Annuitize? Results from Swiss Pension Funds, November 2005

1611 Alexander W. Cappelen, Astri D. Hole, Erik Ø. Sørensen and Bertil Tungodden, The Pluralism of Fairness Ideals: An Experimental Approach, December 2005

1612 Jack Mintz and Alfons J. Weichenrieder, Taxation and the Financial Structure of German Outbound FDI, December 2005

1613 Rosanne Altshuler and Harry Grubert, The Three Parties in the Race to the Bottom: Host Governments, Home Governments and Multinational Companies, December 2005

1614 Chi-Yung (Eric) Ng and John Whalley, Visas and Work Permits: Possible Global Negotiating Initiatives, December 2005

1615 Jon H. Fiva, New Evidence on Fiscal Decentralization and the Size of Government, December 2005

1616 Andzelika Lorentowicz, Dalia Marin and Alexander Raubold, Is Human Capital Losing from Outsourcing? Evidence for Austria and Poland, December 2005

1617 Aleksander Berentsen, Gabriele Camera and Christopher Waller, Money, Credit and Banking, December 2005

1618 Egil Matsen, Tommy Sveen and Ragnar Torvik, Savers, Spenders and Fiscal Policy in a Small Open Economy, December 2005

1619 Laszlo Goerke and Markus Pannenberg, Severance Pay and the Shadow of the Law: Evidence for West Germany, December 2005

1620 Michael Hoel, Concerns for Equity and the Optimal Co-Payments for Publicly Provided Health Care, December 2005

1621 Edward Castronova, On the Research Value of Large Games: Natural Experiments in Norrath and Camelot, December 2005 
1622 Annette Alstadsæter, Ann-Sofie Kolm and Birthe Larsen, Tax Effects, Search Unemployment, and the Choice of Educational Type, December 2005

1623 Vesa Kanniainen, Seppo Kari and Jouko Ylä-Liedenpohja, Nordic Dual Income Taxation of Entrepreneurs, December 2005

1624 Lars-Erik Borge and Linn Renée Naper, Efficiency Potential and Efficiency Variation in Norwegian Lower Secondary Schools, December 2005

1625 Sam Bucovetsky and Andreas Haufler, Tax Competition when Firms Choose their Organizational Form: Should Tax Loopholes for Multinationals be Closed?, December 2005

1626 Silke Uebelmesser, To go or not to go: Emigration from Germany, December 2005

1627 Geir Haakon Bjertnæs, Income Taxation, Tuition Subsidies, and Choice of Occupation: Implications for Production Efficiency, December 2005

1628 Justina A. V. Fischer, Do Institutions of Direct Democracy Tame the Leviathan? Swiss Evidence on the Structure of Expenditure for Public Education, December 2005

1629 Torberg Falch and Bjarne Strøm, Wage Bargaining and Political Strength in the Public Sector, December 2005

1630 Hartmut Egger, Peter Egger, Josef Falkinger and Volker Grossmann, International Capital Market Integration, Educational Choice and Economic Growth, December 2005

1631 Alexander Haupt, The Evolution of Public Spending on Higher Education in a Democracy, December 2005

1632 Alessandro Cigno, The Political Economy of Intergenerational Cooperation, December 2005

1633 Michiel Evers, Ruud A. de Mooij and Daniel J. van Vuuren, What Explains the Variation in Estimates of Labour Supply Elasticities?, December 2005

1634 Matthias Wrede, Health Values, Preference Inconsistency, and Insurance Demand, December 2005

1635 Hans Jarle Kind, Marko Koethenbuerger and Guttorm Schjelderup, Do Consumers Buy Less of a Taxed Good?, December 2005

1636 Michael McBride and Stergios Skaperdas, Explaining Conflict in Low-Income Countries: Incomplete Contracting in the Shadow of the Future, December 2005

1637 Alfons J. Weichenrieder and Oliver Busch, Artificial Time Inconsistency as a Remedy for the Race to the Bottom, December 2005

1638 Aleksander Berentsen and Christopher Waller, Optimal Stabilization Policy with Flexible Prices, December 2005 
1639 Panu Poutvaara and Mikael Priks, Violent Groups and Police Tactics: Should Tear Gas Make Crime Preventers Cry?, December 2005

1640 Yin-Wong Cheung and Kon S. Lai, A Reappraisal of the Border Effect on Relative Price Volatility, January 2006

1641 Stefan Bach, Giacomo Corneo and Viktor Steiner, Top Incomes and Top Taxes in Germany, January 2006

1642 Johann K. Brunner and Susanne Pech, Optimum Taxation of Life Annuities, January 2006

1643 Naércio Aquino Menezes Filho, Marc-Andreas Muendler and Garey Ramey, The Structure of Worker Compensation in Brazil, with a Comparison to France and the United States, January 2006

1644 Konstantinos Angelopoulos, Apostolis Philippopoulos and Vanghelis Vassilatos, RentSeeking Competition from State Coffers: A Calibrated DSGE Model of the Euro Area, January 2006

1645 Burkhard Heer and Bernd Suessmuth, The Savings-Inflation Puzzle, January 2006

1646 J. Stephen Ferris, Soo-Bin Park and Stanley L. Winer, Political Competition and Convergence to Fundamentals: With Application to the Political Business Cycle and the Size of Government, January 2006

1647 Yu-Fu Chen, Michael Funke and Kadri Männasoo, Extracting Leading Indicators of Bank Fragility from Market Prices - Estonia Focus, January 2006

1648 Panu Poutvaara, On Human Capital Formation with Exit Options: Comment and New Results, January 2006

1649 Anders Forslund, Nils Gottfries and Andreas Westermark, Real and Nominal Wage Adjustment in Open Economies, January 2006

1650 M. Hashem Pesaran, Davide Pettenuzzo and Allan G. Timmermann, Learning, Structural Instability and Present Value Calculations, January 2006

1651 Markku Lanne and Helmut Luetkepohl, Structural Vector Autoregressions with Nonnormal Residuals, January 2006

1652 Helge Berger, Jakob de Haan and Jan-Egbert Sturm, Does Money Matter in the ECB Strategy? New Evidence Based on ECB Communication, January 2006 